\title{
Modeling of porous concrete elements under load
}

\author{
B.H. Demchyna1, Yu.Ye. Famuliak ${ }^{2}$, Kh.B. Demchyna ${ }^{3}$ \\ ${ }^{1}$ Lviv Polytechnic National University, Institute of Environmental Building and Engineering, Department of \\ Building Constructions and Bridges \\ e-mail: bogdan195809@gmail.com \\ ${ }^{2}$ Lviv National Agrarian University, Faculty of Building and Architecture, Department of Building \\ Technologies and Organization \\ e-mail: yufam@ukr.net \\ ${ }^{3}$ Lviv Polytechnic National University, Institute of Environmental Building and Engineering, Department of \\ Building Production \\ e-mail: artemenko2185@ukr.net
}

\begin{abstract}
It is known that cell concretes are almost immediately destroyed under load, having reached certain critical stresses. Such kind of destruction is called a "catastrophic failure". Process of crack formation is one of the main factors, influencing process of concrete destruction. Modern theory of crack formation is mainly based on the Griffith theory of destruction. However, the mentioned theory does not completely correspond to the structure of cell concrete with its cell structure, because the theory is intended for a solid body. The article presents one of the possible variants of modelling of the structure of cell concrete and gives some assumptions concerning the process of crack formation in such hollow, not solid environment.
\end{abstract}

Key words: cell concrete, catastrophic failure, crack formation, bubble cell, ball, space model

\section{Introduction}

Modern building uses cell concrete for constructing of a considerable amount of enclosure and load carrying structures. It is also widely used for thermal isolation and sound proofing of premises or fireresistance of separate constructions in general. Considering low strength characteristics of such concretes, it is very important to have a reliable description of the process of destruction of constructive elements, made of cell concretes, providing accurate calculations in projecting of buildings and constructions with application of cell concrete.

It is a well-known fact that cell concretes are fragile and are almost immediately destroyed under load, having reached certain critical stresses in concrete. Such type of destruction is called a "catastrophic failure". Modern theory of concrete destruction, as well as so-called "catastrophic failure" is based on the known Griffith theory $[1,2]$. There are many researchers, engaged in study of the problem, but the researches are mainly focused on heavy concretes [3, 4].

Cracks are considered the crucial factor, influencing strength, load carrying capacity and resistance of constructions, made of fragile material, particularly cell concrete [5, 6]. Formations of cracks, their extension in a construction element and width, prove certain "drawbacks" and critical stresses or 
loads, occurring in the process of the construction exploitation. Thus, formation and development of cracks is of great importance in construction elements.

Published works confirm that appearance and growth of cracks can be classified according to the following factors:

$\checkmark$ technologically production factors: the cracks, having appeared in the process of construction production, particularly shrinkage cracks, connected with conditions of concrete curing in the construction production, at the moment of transition of forces of reinforcement primary load on concrete, etc;

$\checkmark$ exploitation cracks: the cracks, caused by exploitation and excessive loads, taken by construction in the process of exploitation, and the cracks from external impacts (process of freezingdefrosting), etc.

Task of our research is to study the process of modelling of operation of construction elements, made of cell concretes, under load with consideration of peculiarities of such kind of concrete.

\section{Main part}

The research required development of a set of studied samples in the form of $10 \times 10 \times 10 \mathrm{~cm}$ blocks, made of non-autoclaved aerated and gas concrete, for study and statistical analysis of the structure of cell concrete elements. After concrete setting, surface cement skin was removed from the surface of the blocks and it was flushed out with compressed air. Such procedure was necessary to obtain the structure of cell concrete. After purification, the blocks surface was shot. A sample with a square hole and scale was used while shooting to assess sizes of bubble cells of cell concretes. Size of the square hole constituted $50 \times 50 \mathrm{~mm}$. Division value of the scale was $5 \mathrm{~mm}$. Results of the shooting are presented at the fig. 1.

One can see at the fig. 1 that bubble cells of air in the structure of concrete have a size from 0,5 to 4 $\mathrm{mm}$. Generally, they can be conditionally divided into three groups: "small", "medium size" and "large". Under such division, ratio of diameters of the bubble cells, in most cases, make 1:2:4. Besides, the figure shows that increase of strength of the cell concrete (transition from thermal isolation concrete to constructive one) is accompanied by a smaller bubble cells, i.e. porosity of the material decreases, while its weight increases.

Under such structural distribution, which is particular for most cell concretes, one can model the following possible variants of combination of bubble cells of concrete in a volume unit. Let us extract an elementary volume, combining a possible location of such bubble cells in space, out of a piece of concrete and present such variants schematically. Special attention should be paid to possible variants of their location.

Let us choose an elemental area of a single size, which crosses at least three bubble cells, that is particular for cell concretes. Such assumption can be made according to a statistical analysis of the structure of such concrete surface. The further analysis of the obtained images and probability of combination of such bubble sells enables grouping of possible variants into three groups. As it was mentioned above, in the modelling, "small", "medium size" and "large" cells are accepted:

$\checkmark$ the first group - in the area, there are bubble cells of the same size, which border on bubble cells of another or the same size above and below, while their amount is different;

$\checkmark$ the second group - in the area, there are bubble cells of the same size, which border on bubble cells of another or the same size above and below, while their amount is the same;

$\checkmark$ the third group - combines bubble cells in the area and also those, which are above and below, having different size. 

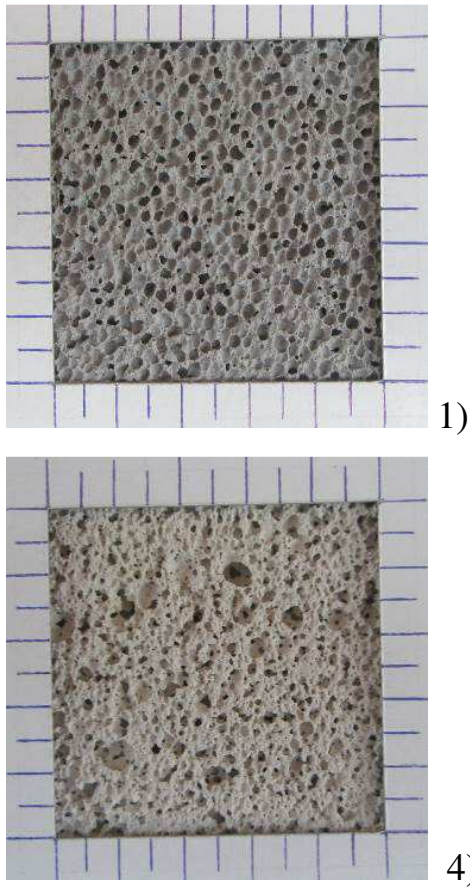

4)

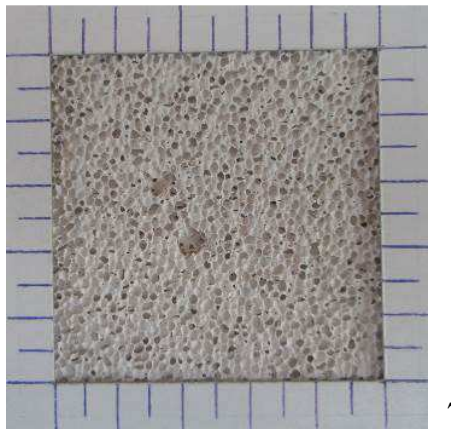

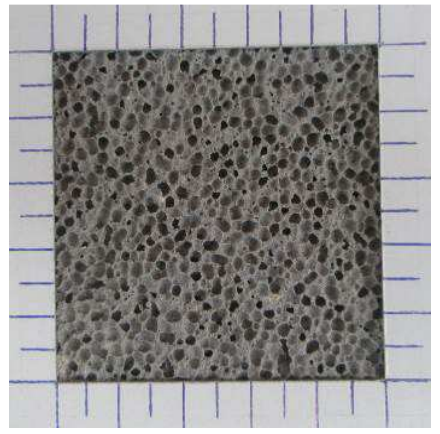

2)
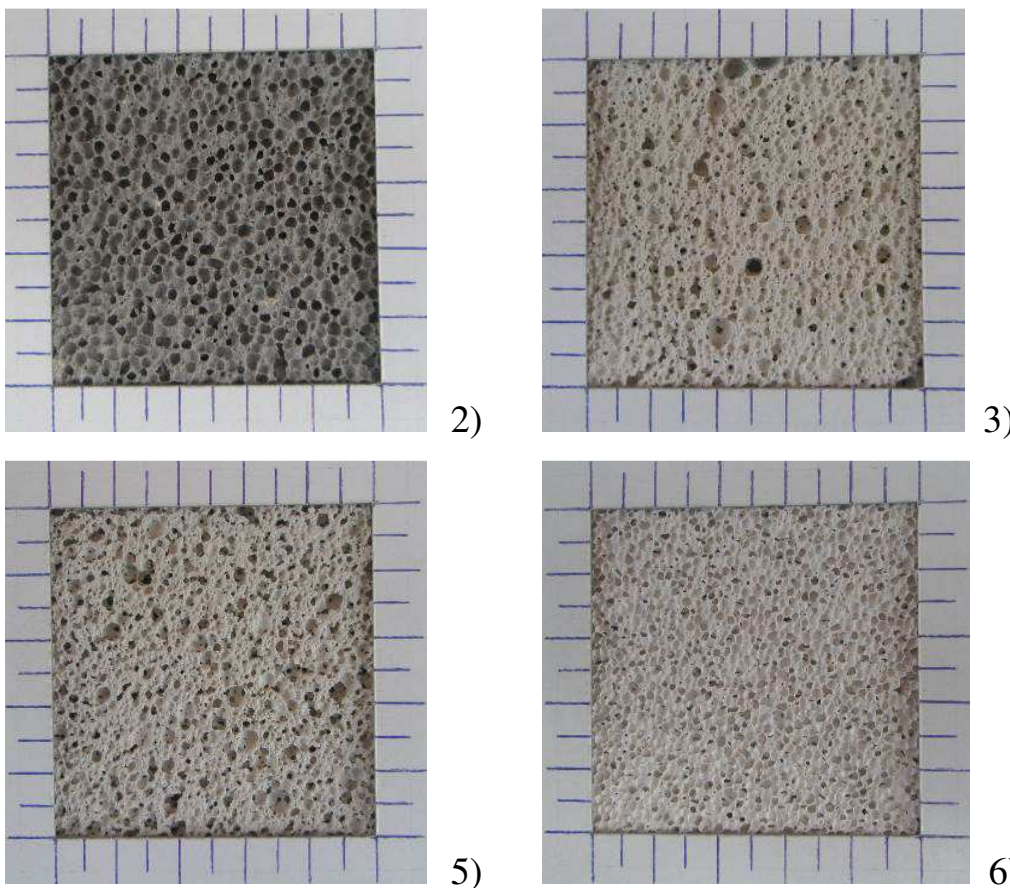

5)

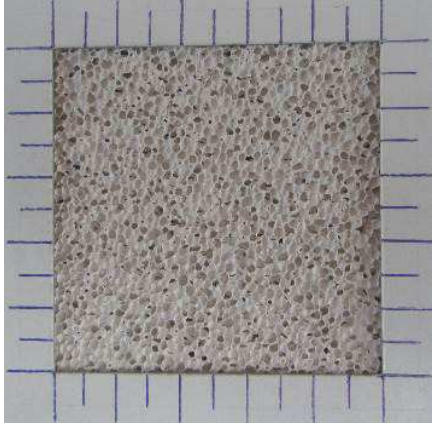

6)

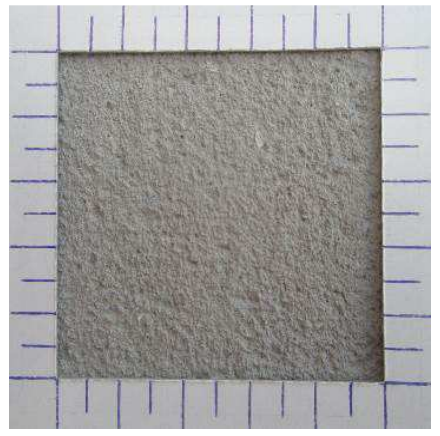

8)

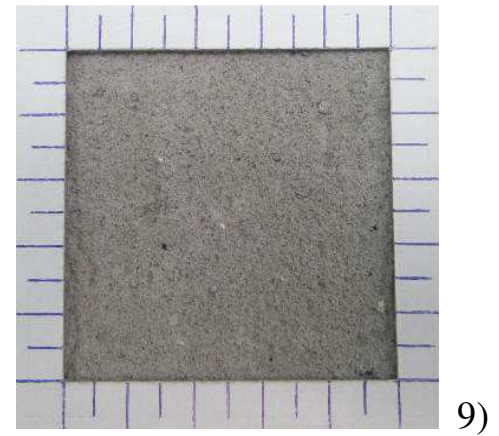

Figure 1: Image of cell concretes of different types:

1) ... 5) - aerated concrete of thermal isolation; 6), 7) - gas concrete of thermal isolation and construction; 8), 9) - aerated constructive concrete.

Graphical depiction of the groups is presented in the table 1 . One should note that bubble cells are presented in the form of balls of different diameter, and an elementary volume - in the form of cylinder. Ratio between the diameters of balls is taken as 1:2:4. Overall sizes of the elementary volume (cylinder) are accepted the following ones. The cylinder diameter is equal to the diameter of the circle, which connects centers of balls, which are in the same area, in case of the similar balls. In case there are balls of different sizes in the area, diameter of the circle, and thus, diameter of the cylinder, is determined by the smallest ball. Height of the cylinder is taken as equal to the diameter. Besides, there is accepted a certain margin between the balls (in our case, it is taken as $0,1 \cdot R$, where $R$ - is a radius of the smallest ball in incorporation). 
Table 1: Scheme of balls incorporations

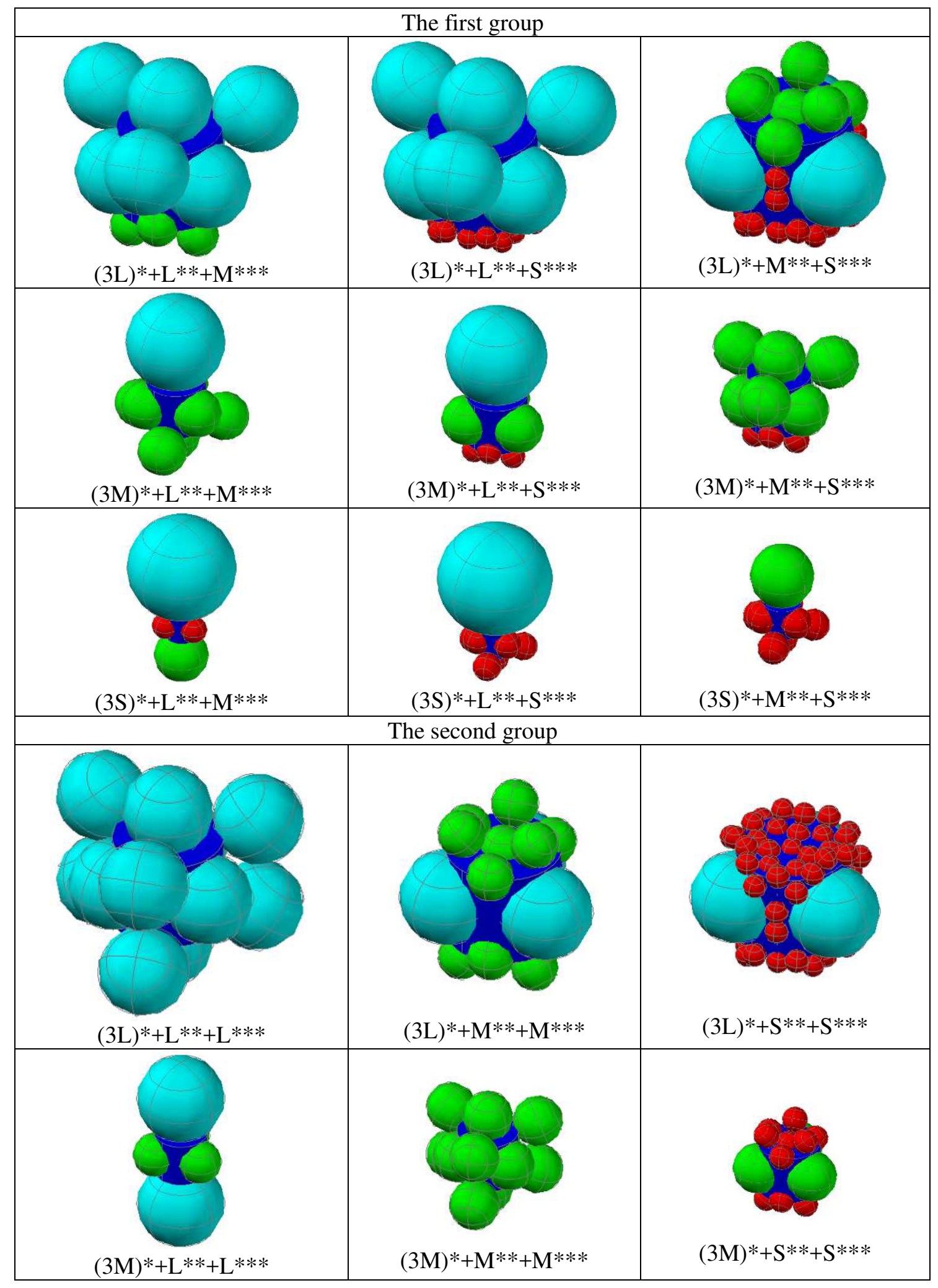




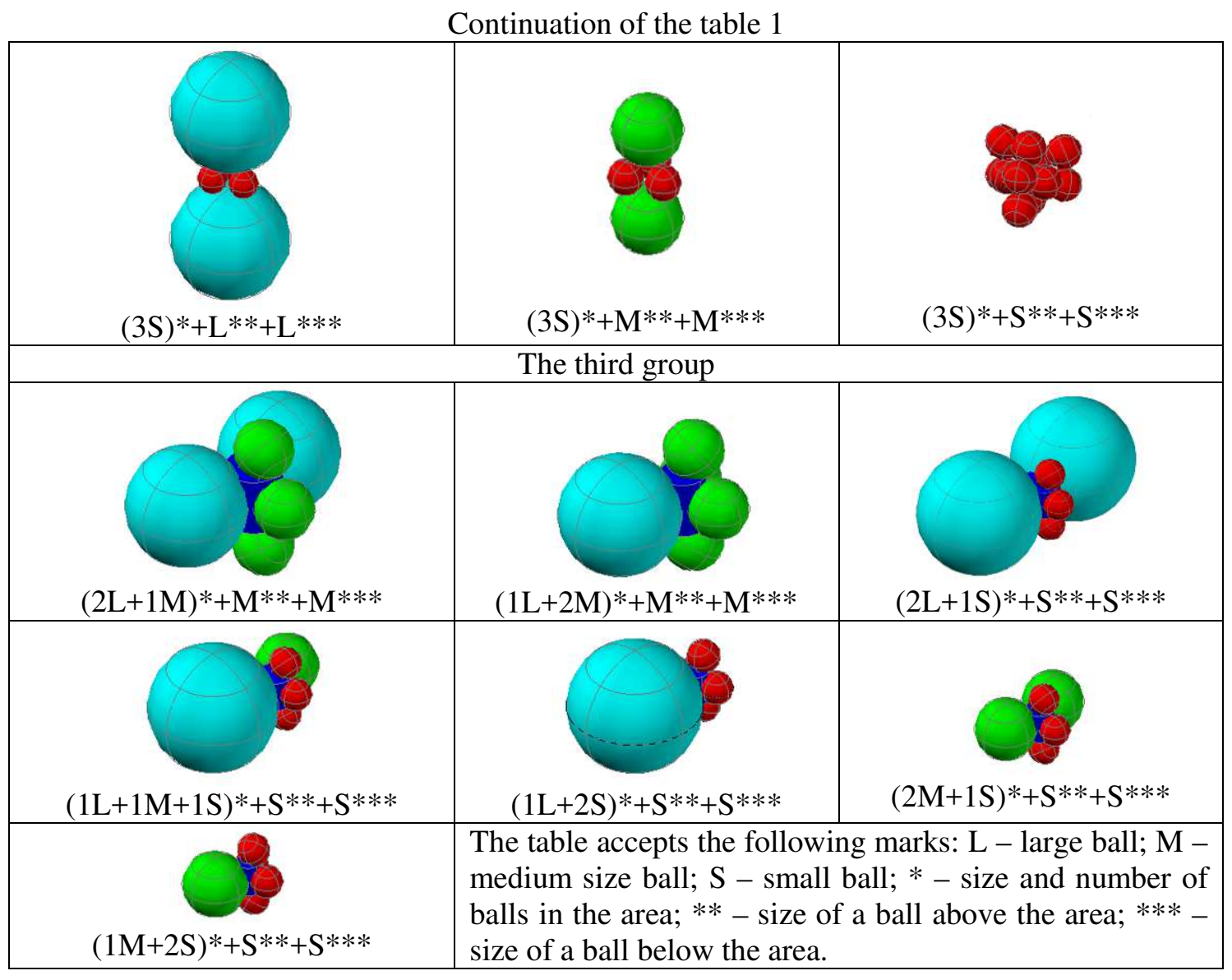

The further modelling of the structure of cell concretes included the following operation, i.e. volume of balls (bubble cells) was extracted of the volume of cylinder (elementary volume). Thus, the research obtained elementary volumes, which can be used for modelling of the structure of cell concrete with high accuracy. The process of transformation is presented by the fig. 2 .

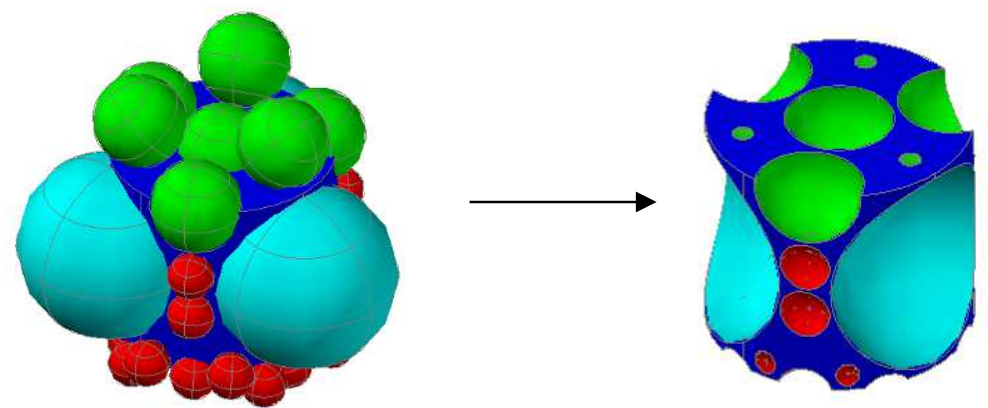

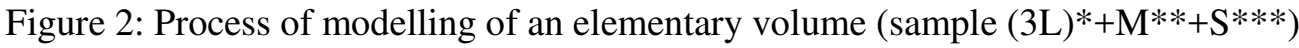

To determine stresses, occurring in elementary volumes of cell concretes, Ansys software was applied. The program supplied a picture of stresses in the elements under conditions of pressing and expansion of the last ones. In the process of modelling, down surface of the cylinder (elementary volume) was hard fixed, and equally distributed load was applied on the top surface of the cylinder. In case, there were balls of different sizes above and below the middle area of balls, modelling of operation under load was carried out twice: the first time, down surface was fixed and second time - the top surface of the cylinder was fixed (for better demonstration, the cylinder was turned by $180^{\circ}$ ) 
The carried out modelling resulted in a quantitative picture of stresses in an elementary volume (cylinder) of cell concrete (fig. 3).
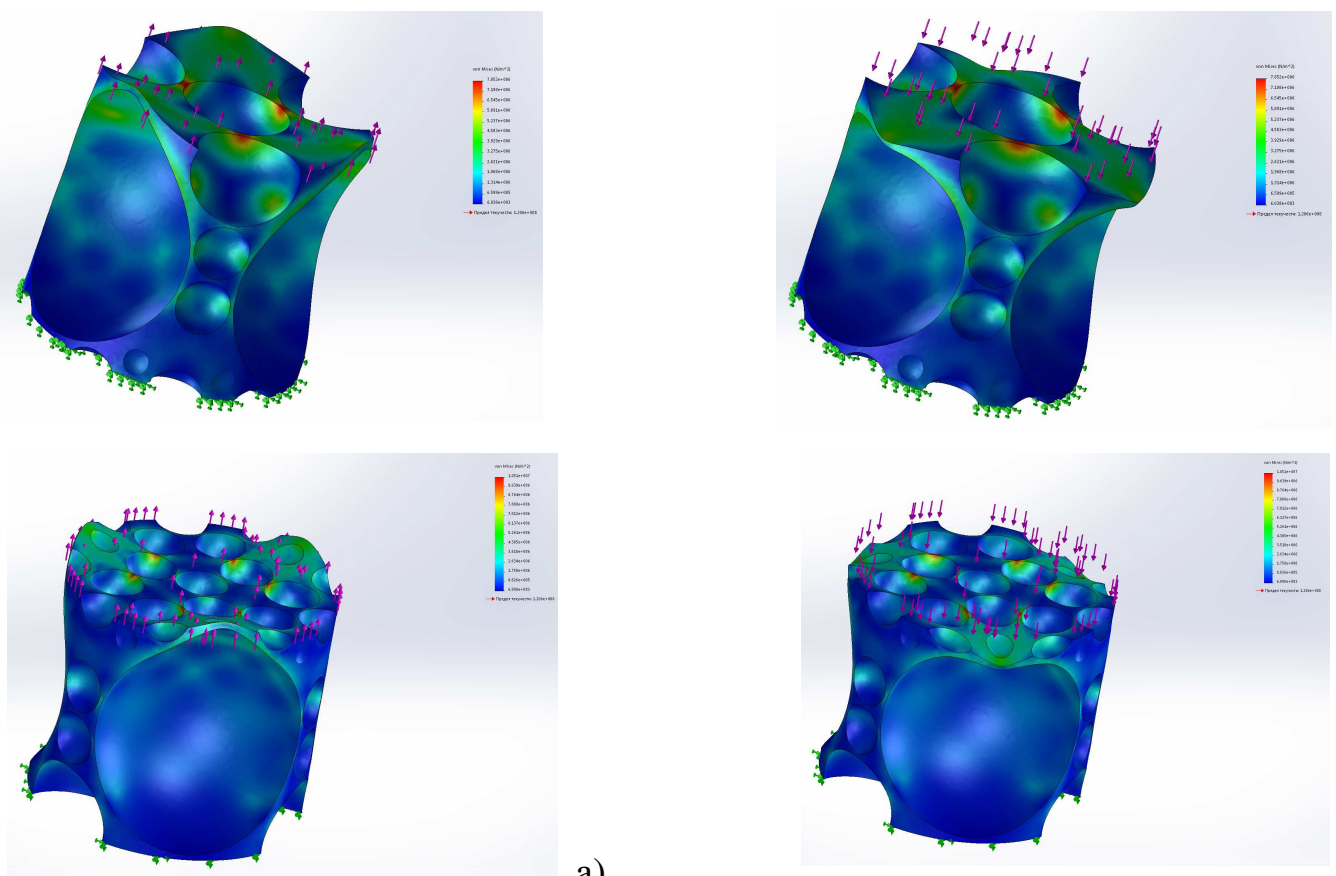

a)

б)

Figure 3: Results of modelling of operation of an elementary volume of cell concrete under load (sample $\left.(3 \mathrm{~L})^{*}+\mathrm{M}^{* *}+\mathrm{S} * * *\right)$ :

a) applied extension forces; $b$ ) applied pressing forces

A permanent load for all samples was accepted for the modelling, particularly surface of the cylinder (elementary volume) was subjected to the stress of $1000 \mathrm{~N} / \mathrm{m}^{2}$. Results of the testing are grouped and presented in graphical form at the fig. 4. The graphics demonstrate elementary volumes (cylinders) of the first and the second groups (see table 1).

As one can see at the graphics, stress in an elementary volume of cell concrete depends on a type of balls incorporation, i.e. it depends on size of bubble cells in a body of cell concrete.

Having made a detailed analysis of the obtained results, one sees that in the process of loading of such elementary volumes, which model operation of cell concretes, maximum stresses occur in the place of minimum width of the wall between cavities, that really model cement stone of the concrete piece. Increase of the load forces critical stresses in the places and shell of bubble cell starts its destruction, i.e. cracks appears, extending in the direction of the next point of connection with another bubble cell. Thus, the piece of the cell concrete experiences the process of crack formation. 


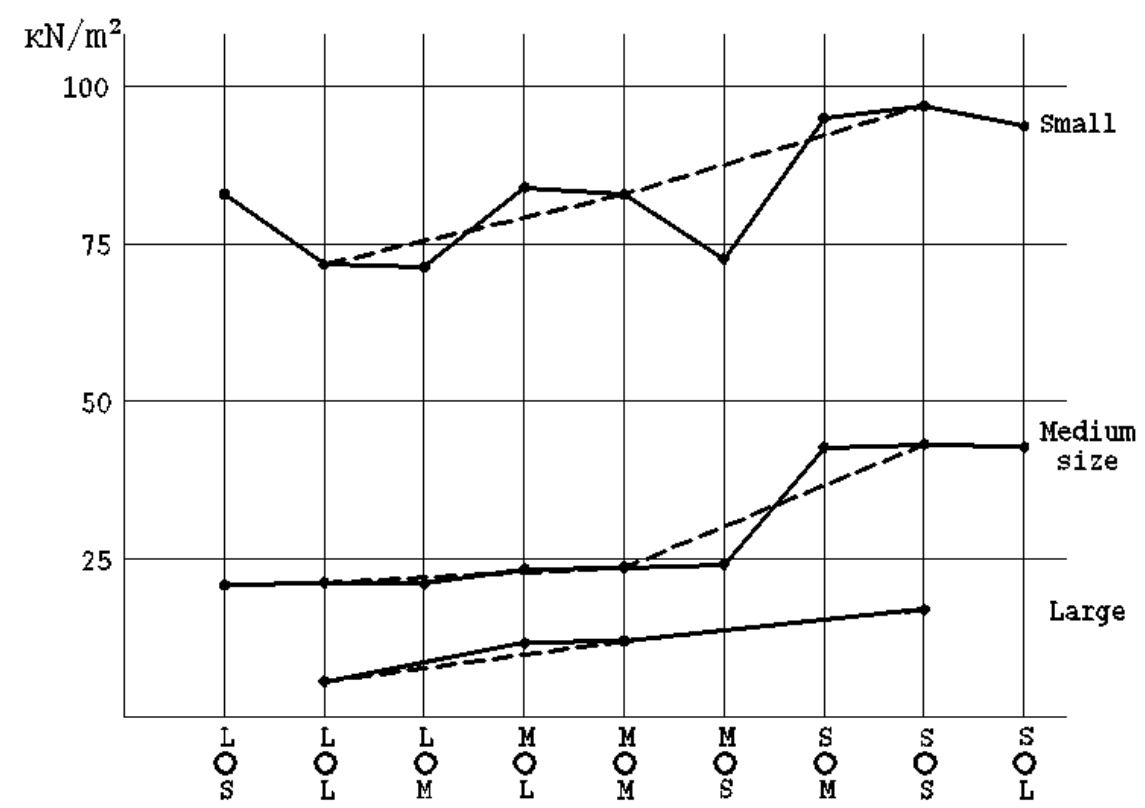

Figure 4: Graphics of dependences of maximum stresses in an elementary volume on the type of incorporation of hollow balls:

_ $\quad$ stress at pressing; _ $\quad----$ stress at extension

\section{Conclusions}

According to the results of the carried out theoretical research, one can make the following conclusions:

- proposals concerning application of hallow balls for modelling of the structure of cell concretes gives rather realistic presentation of the amount of cell concretes;

- application of hollow balls in modelling of operation of construction elements, made of cell concrete, provides better description of complicated processes, occurring in a piece of such concrete under load;

- process of crack formation in cell concrete substantially differs from the process of crack formation in heavy concrete and thus, the existing theories do not provide realistic description of the process in cell concretes.

\section{References}

[1] Cherepanov G.P. Mechanics of brittle fracture / G.P. Cherepanov. - M.: Nauka, 1974. - 640 p.

[2] Destruction of concrete and its durability [Guzeev E.A., Leonovich S.N., Milovanov A.F. and etc.] ; For the general revision of E.A. Guzeeva. - Minsk: Tydzen, 1997. - 170 p.

[3] Karzov G.P. Physico-mathematical modeling of fracture processes / G.P. Karzov, B.Z. Margolin, V.A. Shvetsov. - K.: 1993. 391 p.

[4] Karpenko N.I. General models of the mechanics of reinforced concrete / N.I. Karpenko. - M.: Stroiizdat, 1996. - $416 \mathrm{p}$.

[5] Piradov K.A. Mechanics of destruction of reinforced concrete / K.A. Piradov, E.A. Guzeev. - M.: NIIAB, 1998. - 190 p. 
[6] Romanenko V.M. Concerning the determination of the moment of formation of normal cracks in bending reinforced concrete elements / V.M. Romanenko // Building constructions. - Issue 74. K.: Budivelnik, 2011. - P. 365 - 372. 